\title{
PROTECTING THE BUILT ENVIRONMENT OF ALBERTA AND THE NORTHWEST TERRITORIES
}

\author{
MARC C. DENHEZ*
}

\begin{abstract}
The author canvasses the present and alternate approaches to the preservation of valuable buildings at the provincial, municipal and private levels. Heritage legislation in Alberta and the Northwest Territories is examined from a practical viewpoint, giving rise to such questions as: the extent to which assessment of the environmental impact of proposed development is ordered; the types of designation of historical sites and the effects of each; and the use and effects of planning and zoning provisions.
\end{abstract}

\section{INTRODUCTION}

\section{A. Context}

For the large majority of Canadians, "environment" is their city or town; it is in a city or town that they reside, work, and spend most of their leisure hours. Inevitably, the quality of this urban or semi-urban environment will have a significant impact upon their everyday life, with such matters as stress, cultural identity, and sense of historic continuity affected by it. The conservation of the built environment is therefore of great importance not only to the conservation movement, but also to municipal planners, officials, and experts on land use controls; the cultural and aesthetic values represented by the buildings which constitute the environment of most of our population deserve our close attention.

Clearly, one way for such buildings to be saved is through purchase by someone dedicated to their retention; but since it is impossible to thus acquire all valuable buildings, this article looks at alternate approaches. There are legal mechanisms at five levels: international, federal, provincial, municipal, and private. Furthermore, public participation is an important dimension to any discussion of land use controls. Finally, it is also possible to apply for financial assistance to a number of sources. Though canvassed briefly later in this article, the relevant agencies should be contacted directly.

The international and federal aspects of protecting the built environment have already been described by this writer in a previous publication. ${ }^{1}$ The salient features of that detailed description can be summarized as follows.

\section{B. International Aspects}

"Heritage legislation" is defined, by international consensus, as the body of law which deals with the identification and protection of sites and areas of historic and/or architectural interest. Financial aid to such sites and areas is often considered a further component of such legislation, although it is not usually described in the statutes themselves.

* B.C.L., Member of the Bar of Quebec, and the Law Societies of Upper Canada and the Northwest Territories; Canada's representative on the UNESCO-sponsored international joint study of legal and financial techniques of heritage conservation. This article was prepared with the assistance of Merike Madisso, LL.B., and the Canadian Environmental Law Research Foundation.

1. Protecting the Built Environment Part I (Heritage Canada, Ottawa, 1978). The French version of this work was published in La Revue du Barreau, Sept. Oct. 1978. 
International treaties such as The Hague Convention of 1954 and the UNESCO World Heritage Convention of 1972 were drafted to promote the protection of architecture and historic sites. When Canada adhered to the latter treaty in 1976, it formally committed itself to a number of objectives concerning heritage protection, including the integration of conservation principles into national policy. ${ }^{2}$ These obligations have not been translated into statute.

International treaties have been supplemented by international Recommendations which outline the contents of proper heritage legislation. Canada voted for these Recommendations; however, unlike treaties, they are not legally binding upon Canada.

\section{Interpretation}

Heritage legislation now exists in Canada. In order to protect heritage property it is sometimes necessary to restrict the owner's right to alter or destroy that property. Although there is nothing intrinsically "unconstitutional" or "illegal" about such controls, courts must sometimes decide, in cases of legal uncertainty, whether the benefit of the doubt is to be given to the owner or to the heritage authorities. Although this issue has yet to be firmly decided, most precedents suggest that heritage authorities should enjoy the benefit of the doubt. ${ }^{3}$

\section{Federal Aspects}

Most authority for the protection of heritage belongs to the provinces. The federal government has entrusted a large heritage program to Parks Canada, but the extent to which it can actually protect buildings against demolition is severely limited by constitutional factors. For example, the federal Historic Sites and Monuments Act does not protect buildings against demolition. ${ }^{4}$

The federal government can presumably protect buildings if it actually buys them. However, the Canadian federal government, unlike some foreign governments, is under no legal obligation to protect the heritage which is in its hands. This distinguishes the federal government's legal obligations from those of other countries, which are by treaty obliged to respect Canada's heritage sites; it also distinguishes Ottawa's domestic obligations from its foreign ones, where by treaty it is obliged to respect the heritage sites of other countries. ${ }^{5}$

The federal government has, however, established special nonstatutory administrative procedures to minimize the effect of public works which damage heritage. ${ }^{6}$

In the absence of statutory controls on federal heritage property, the question has arisen whether such property could be subjected to provincial heritage laws; but most authorities contend that federal property is exempt from such provincial legislation. ${ }^{7}$

2. A description of the legal consequences of these treaties is found in the above publication, at $4-5$.

3. The above publication reviews most of the major jurisprudence affecting burden of proof in "heritage" cases. See pp. 7-11.

4. A description of these limitations, particularly those found in the British North America Act, is found in the above publication at 11-17.

5. These various obligations result from the treaties mentioned earlier.

6. The above publication describes the basic features of "environmental impact" procedures at the Canadian federal level as compared with the U.S. and Australia, at 13-14.

7. Supra n. 1 at 14. 
There is some property which, without being federally owned, is under direct federal control: railway property and harbours are examples. Federal agencies supervise this property, but it is not clear whether these agencies can protect heritage. Although it was often assumed that such property shared the same immunity from provincial laws (including heritage laws) as federal property, that assumption has been shaken by recent litigation: such property can probably be subjected to provincial and municipal heritage controls. ${ }^{8}$

The federal government operates several subsidy schemes which can be useful for the renovation of buildings. However, the federal Income Tax Act treats a demolished investment property as "lost", and recognizes a substantial tax deduction on demolition accordingly. Furthermore, the Income Tax Act provides no incentives for renovation; this can leave renovation in a poorer position tax-wise than new construction. ${ }^{9}$ This question is currently the subject of substantial discussion and negotiation, and holds out the distinct possibility of change. ${ }^{10}$

Finally, the federal government exercises direct jurisdiction over several protective measures in the territories. These will be discussed later in this article in the context of the Northwest Territories.

\section{E. Other Aspects}

This article discusses the other aspects of legislation to protect the built environment, namely, the provincial, territorial, municipal and private contractual aspects, including the feature of citizen participation. In many respects these are the most important aspects of the subject.

An overview of provincial, territorial and municipal powers in this area has already been published in order to compare the legislative provisions in any one province with those of any other province or territory in Canada.11 The following article will now consider those features of the question which arise directly out of the legislation of Alberta and the Northwest Territories.

\section{THE PROVINCIAL LEVEL}

\section{A. Early Warning System and Governmental Demolition}

Before a government can take action to protect historical resources it must know that these valuable resources exist. Accordingly, the United States and Australia have developed an "environmental impact assessment" procedure, which requires that careful inventory and investigation precede major works likely to affect the environment (including the built environment) and financed, at least in part, by government.

Much of this procedure has been adopted by Alberta for the purposes of heritage conservation. The Land Surface Conservation and Reclama-

8. Hamilton Harbour Commissioners v. City of Hamilton (1978) 1 M.P.L.R. 133 (Ont. S.C.), on which this view was based, was appealed unsuccessfully to the Ontario Court of Appeal: (1979) 21 O.R. (2d) 459. Appeal to the Supreme Court of Canada was abandoned.

9. Supra n. 1 at 17-19. A more detailed description is found in "Current Tax Proposals Affecting Renovation", by this writer, in Second Canadian Building Congress (National Research Council, Ottawa, 1980).

10. For a description of current developments in this area, see Heritage Canada Magazine, May 1979, at 3-4.

11. Supra n. 1 at $20-23$. 
tion Act ${ }^{12}$ authorizes the Alberta Department of the Environment to order the preparation of reports assessing the environmental impact of proposed development. The Act specifies factors to be included in the reports, some of which are impact on the conservation, management, and utilization of natural resources; the prevention and control of pollution; economic factors that relate to environmental matters; and preservation of natural resources for their aesthetic value. The Act also requires consideration of alternatives to the proposed development. ${ }^{13}$

Alberta authorities require impact assessment for historical resources. Consequently, whenever a major public work project is proposed, such as a highway or a dam, its impact on these historical resources must be reported and an explanation of possible alternatives must be included. The report is then submitted to the Department of the Environment or to one of its agencies. Changes in the project may be ordered so as to protect threatened heritage assets.

Unlike the American example, however, there appears to be no formal mechanism whereby citizens can appeal the government's decision to the courts. ${ }^{14}$

Two moves have broadened the scope of environmental assessment in Alberta. First, the Minister of Culture is empowered, under the Alberta Historical Resources Act, ${ }^{15}$ to order environmental impact assessments in cases which might not otherwise be covered by the Land Surface Conservation and Reclamation Act. Secondly, these reports are becoming obligatory not only for the public sector, but also for part of the private sector: for example, all developers of energy resources must file such reports when proposing projects. ${ }^{16}$

Most of the reports submitted deal with archaeological resources, and it is not immediately clear when the effect of this legislation will be felt by a proposed demolition of historic buildings. Although the latter theoretically qualify as "development" under the legislation, authorities have not yet used environmental impact assessments to impede the demolition of buildings by public projects; there is, nevertheless, a possibility that this mechanism could be so used in the future.

In the Northwest Territories, there is a highly complex system of permits required for a wide assortment of operations. ${ }^{17}$ Most of these permits require an impact assessment of some description; however, although archaeological resources are frequently mentioned, there is no statute or ordinance which specifically deals with projects threatening existing buildings, or which provides a public forum to oppose such threats. Until such time as special ordinances on the subject are passed

12. S.A. 1973 , c. 34 , s. 8 .

13. Environmental Impact Assessment Guidelines, Alberta Environment, 1977, at 1.

14. This is in marked contrast to the American system, where there are usually twenty to thirty citizens' applications for injunctions pending before American courts at any given time to block projects threatening heritage. See the National Historic Preservation Act (U.S.A.) of 1966, 16 U.S.C. 8. 470 (f), particularly at s. 106; National Environmental Policy Act, 42 U.S.C. 8. 4321, P.L. 91-190 (1970). An updated list of U.S. litigation to protect historic sites is issued periodically by the National Trust for Historic Preservation, 740 Jackson Place, Washington, D.C.

15. S.A. 1973 , c. 5 , s. $22(2)$.

16. See Energy Resources Conservation Board Interim Directive ID-G 77-1.

17. These mechanisms are outlined in considerable detail in Land Use Programs in Canada: the Northwest Territories. Environment Canada Lands Directorate, Ottawa, 1979. 
for the Northwest Territories it would probably be expedient to attempt to use the same recourses as those outlined for the federal level. ${ }^{18}$

\section{B. Federal-Territorial Protection of Property}

\section{The Historical Resources Ordinance}

The Northwest Territories has an ordinance called the Historical Resources Ordinance, ${ }^{19}$ which deals with the "commemoration" of heritage sites.20 This "commemoration" does not, however, have the legal effect of protecting a property against alteration or demolition and in that respect, the ordinance differs from most provincial statutes which have similar titles and objects. ${ }^{21}$ In order to find protective provisions one must look to other enactments, which are described below.

\section{The Northwest Territories Archaeological Sites Regulations}

Certain powers have been granted to authorities enabling them to protect endangered heritage property. The Northwest Territories Act ${ }^{22}$ empowers the federal cabinet to enact "regulations for the protection, care and preservation of sites, works, objects and specimens of archaeological, ethnological, or historical importance."23 Accordingly, in 1960 the federal cabinet enacted the Northwest Territories Archaeological Sites Regulations. ${ }^{24}$

One should not be misled by the title. The regulations give a wide definition of "archaeological sites": that term includes sites of "ethnological or historical importance". It therefore appears that, for legal purposes, such a site can include existing structures and not only ruins.

The Regulations confer certain powers on the federal "Minister of Northern Affairs and National Resources"25 (now called the Minister of Indian Affairs and Northern Development). On the subject of the protection of buildings against alteration and demolition, those powers are not as clearly worded as those of heritage statutes in the provinces: ${ }^{26}$ instead of stating that the Minister can designate sites which are henceforth protected, section 6 of the Regulations states that "no permit shall be issued for the removal or excavation of any structure that, in the opinion of the Minister, should be permanently preserved in situ (i.e., in that location) as an object of scientific or historic interest". This creates the inference that the Minister could designate various sites of "scientific or historic interest" which henceforth could not be "removed". Since it is common in the terminology of land use controls to include demolition as a form of "removal" of a structure, a building so designated by the Minister would, presumably, be protected against demolition. This hypothesis, however, is still untested in the Northwest Territories. Most people still think of the Regulations as applying to "archaeological sites" in the strict

18. Supra n. 1.

19. R.O.N.W.T. 1970 , c. H-2.

20. Id. at $\mathrm{s.}$ 3(b).

21. See Alberta Historical Resources Act, s. 18; British Columbia Heritage Conservation Act, Parts II, III; Manitoba Historic Sites and Objects Act, 88. 3, 19; New Brunswick Historic Sites Protection Act, 88. 2, 3; Newfoundland Historic Objects, Sites and Records Act, 88. 17, 20; P.E.I. Recreation Development Act, ss. 24, 31; Saskatchewan Heritage Act, s8. 6, 9.

22. R.S.C. 1970 , c. N-22.

23. Id. at 8. 52.

24. SOR Cons. 1978, c. 1237. See Canada Gazette Part II, Vol. 94, at 100.

25. Id. at 8. $2(1)(\mathrm{c})$.

26. Supra n. 21. 
sense (not in the legal sense), and consequently have been reluctant to use this mechanism for the protection of other heritage sites.

\section{The Area Development Ordinance}

The Area Development Ordinance ${ }^{27}$ empowers the Commissioner of the Northwest Territories to designate "development areas" in "any area of the Territories".28 In a development area, the Commissioner can prohibit the "erection . . . alteration, repair or removal of buildings". ${ }^{29}$ It consequently appears that he can protect heritage areas by designating them development areas and then enacting appropriate protective controls.

There is, however, a small problem. Although the Ordinance states specifically (at section 3) that such areas can be designated anywhere in the Territories, the long version of the title of the Ordinance is "An Ordinance to Provide for the Orderly Development of Unorganized Areas". This title suggests that "development areas" could be designated only outside municipal boundaries. That problem can, however, be overcome. As one authority put it: ${ }^{30}$

A title is never allowed to affect or restrain the plain meaning of a statute, but only to act as an aid in resolving a difficulty. The principle is that where something is doubtful or ambiguous, the long title may be looked at to resolve the doubt or ambiguity. But in the absence of doubt or ambiguity, the passage under construction must be taken to mean what it says, so that if its meaning be clear, that meaning is not to be narrowed or restricted by reference to the long title.

It therefore follows that if section 3 of the Ordinance states that "development areas" can be designated "in any area of the Territories", then those areas can be designated in any area whether it is within municipal boundaries or not. This hypothesis, however, is still untested in the Northwest Territories.30a

\section{The Protection of Individual Sites in the Northwest Territories}

If one adopted the untested hypothesis (explained earlier) that the Minister of Indian Affairs and Northern Development can prohibit demolition under section 6 of the Northwest Territories Archaeological Sites Regulations, protection of property against demolition could be obtained by designating it under that Regulation. Demolition could not, presumably, proceed thereafter without ministerial consent. However, the Regulations do not specifically mention alteration of buildings; they simply state that the site should be specifically preserved. Would alteration be inconsistent with "preservation"? It is not immediately clear whether such a designation would prevent an owner from altering his property beyond recognition. One may attempt to draw the inference.that this would be contrary to "preservation" and hence that this activity would be illegal; while that inference is perfectly plausible, it has yet to be tested in court.

27. R.O.N.W.T. 1974 , c. A-5.

28. Id. at 8. 3.

29. Id. at s. $4(\mathrm{~b})$.

30. Craies on Statute Law (7th ed. S. G. Edgar ed. 1971, Sweet and Maxwell, London) at 194.

$30 \mathrm{a}$. This question must be approached with caution. Other authorities, notably Land Use Programs in Canada: the Northwest Territories, supra n. 17 at 106 and K. P. Beauchamp in Land Management in the Canadian North (Canadian Arctic Resources Committee, Uttawa 1976) at 43 take the view that such declarations can take place only in unorganized areas. However, neither of these authorities cite reasons for their conclusion. 
If one adopted the untested hypothesis that the Area Development Ordinance can both protect buildings in "development areas" against alteration and demolition and control new construction, protection would result from a two-step process. First, the Commissioner would have to designate the area as a "development area". Secondly, he would have to issue land use controls specifying that demolition and alteration would be subject to his approval.

Two points, however, must be remembered. First, although the Area Development Ordinance specifies that an area designated shall not be larger than 150 square kilometres, ${ }^{31}$ nothing says how small it may be; that is, whether it could be small enough to cover only one building and its surrounding property. Although there is no immediate legal impediment to such a designation, it might conceivably be challenged as contrary to the intent of the legislation. Secondly, in the event that the Commissioner did not want to name all the structures in an area for protection, it is also unclear how specific the land use control on demolition would have to be; that is, whether it would need to mention a protected site by name, or whether it could generally foresee protection of "any historical sites" of a definable class. Since the Ordinance has yet to be used for such purposes neither of these questions have been answered by the courts.

\section{The Protection of Individual Sites in Alberta}

\section{General}

The Alberta Historical Resources Act ${ }^{32}$ empowers governmental authorities to designate property for protection. There are two forms of designation: as a "registered historic resource" or as a "provincial historic resource". (In each case the designation is ordered by the Minister of Culture. $)^{32 a}$ The effect of each will be outlined later in this article.

\section{Procedure}

When the Minister decides that a property deserves protection under either form of designation he must notify the "owner", 33 although the Act says nothing about notifying tenants. The Minister is under no obligation to give reasons when notifying an owner of impending designation as a "registered historic resource", but must do so when the notice refers to impending designation as a "provincial historic resource". ${ }^{34}$ Notice, in either case, must also be published in the official Alberta Gazette. ${ }^{35}$

The Act does not specify any special recourse for a person whose property faces impending designation as a "registered historic resource". When the designation at stake is a "provincial historic resource" then "any interested person" may, within 30 days of publication of the notice in the Alberta Gazette, notify the Advisory Historic Sites Board that he wishes to make representations. ${ }^{36}$ When such a request is made a hearing

31. Supra n. 27 at $8.3(2)$.

32. S.A. 1973 , c. 5 , as am

32a. Id. The Minister's designation power concerning Registered Historic Resources is stated at 8. 17(1) of the Act; his power concerning Provincial Historic Resources is stated at s. 18(1).

33. Supra n. 32. Registered Historic Resources: see 8. 17(2)(a). Provincial Historic Resources: see s. 18(2)(a). The notice may be served or sent by registered mail; see s. 18.1.

34. Supra n. 32 at s. 18(3).

35. Supra n. 32. Registered Historic Resources: see s. 17(2)(b). Provincial Historic Resources: see 8. $18(2)(\mathrm{b})$.

36. Supra n. 32 at 8. 18(4). 
must take place at least fifteen days before the Minister proposes to designate the property. ${ }^{37}$

The Act is ambiguous as to the consequences of this hearing if it is held. If the Board recommends in favour of designation, then the Minister "may" proceed. ${ }^{38}$ Alternatively, it appears that the Minister can choose not to proceed. On the other hand, if the Board recommends against designation, then it is not at all clear whether the Minister is entitled to disregard that advice and proceed to designate. A literal reading of the Act suggests that he is not, ${ }^{39}$ but such interpretation would effectively give the Board a kind of veto power and render it more than a purely advisory body. It is questionable whether such an interpretation corresponds to the intention of the legislature. This question has yet to be decided by the courts: owners have not been aware of any negative recommendations by the Board, largely because all recommendations have until now been kept secret.

All designations take effect vis-a-vis the owner as soon as they are served upon him, ${ }^{40}$ sent to him by registered mail, ${ }^{41}$ or published in the Alberta Gazette, ${ }^{42}$ whichever occurs first. They take effect against anyone else as soon as they are published in the Alberta Gazette.43 Designations must also be filed in the local Land Titles Office. ${ }^{44}$ Interim protection is available even before the designation formally takes effect; this feature will be discussed later in this article.

\section{Effect on Registered Historic Resources}

No person shall "destroy, disturb, alter, restore, or repair" a registered historic resource, or remove any "historic objects" from it without giving the Minister of Culture a minimum of 90 days notice. ${ }^{45}$ At the end of this notice the proposed alteration or destruction can proceed. Furthermore, such sites can be exempted from building codes and similar codes. ${ }^{46}$

Finally, the Act states that such resources cannot be transported out of the province without ministerial consent. ${ }^{47}$ This provision is the subject of considerable debate from the viewpoint of constitutional validity, but has little application to buildings.

\section{Effect on Provincial Historic Resources}

The effects of this kind of designation are more significant. In the first place, protection for a "provincial" (as opposed to "registered") historic resource can last indefinitely, rather than for a period of 90 days. No

37. Id. at s. $18(5)$.

38. Id. at $\mathrm{s.} 18(6)$.

39. Id. Section 18(6) states: "If no representations are made or if the Board after hearing any representations recommends that the Minister proceed with the proposed designation, the Minister may proceed to make the order. ..." Are these the only two cases in which the Minister may proceed? Some authorities argue that whenever a proprietor's rights are being infringed, the government must follow the prescribed procedures to the letter, and cannot step outside them; if that view is adopted, then the Minister would have no authority to proceed if the Board rendered a negative recommendation.

40. Supra n. 32. Registered Historic Resources: see 8. 17(4)(a). Provincial Historic Resources: see s. $18(8)(a)$.

41. Supra n. 32. See s. 18.1.

42. Id. Registered Historic Resources: see s. 17(4)(b). Provincial Historic Resources: see 8. 18(8)(b).

43. Id. Registered Historic Resources: see s. 17(3). Provincial Historic Resources: see s. 18(6)(c).

44. Supra n. 32 at $8.17(2)(c)$.

45. Id. at $8.17(5)$.

46. Id. at s. 37 .

47. Id. at $8.20 .3($ c). 
person may "destroy, disturb, alter, restore or repair" such a resource, or remove any heritage object from it without the written authorization of the Minister of Culture; such authorization can be refused indefinitely. ${ }^{48}$

Secondly, the Minister must be notified at least 30 days before any disposition of the property; 49 he must also be notified within 15 days of the transfer pursuant to an inheritance. ${ }^{50}$ Until 1978 the Minister was thereupon empowered to purchase the property at fair market value. That power has now been abolished. ${ }^{51}$

Thirdly, the Minister can insist upon the proper maintenance of such property. ${ }^{52}$

Fourthly, such property can be exempted from building codes and similar codes. ${ }^{53}$

Finally, the Act states that provincial historic resources cannot be transported outside the province without ministerial consent. ${ }^{54}$

\section{E. Reasons for Protection}

What kinds of reasons are required to sustain a designation? If governmental authorities were to designate a property for reasons which are overtly extraneous to the Alberta Historical Resources Act, or the corresponding N.W.T. laws, the designation would be open to challenge in court. ${ }^{55}$ However, if the designation was enacted for the bona fide purpose of protecting heritage, then the "reasons" are not open to attack even if the heritage value of the property is slight: ${ }^{6}$

If there is some evidence [of heritage value] . . . this court cannot substitute its own opinion for that of [the authorities] ... as to whether that evidence was sufficient or good enough, or both, to make the declaration under the Act.

\section{F. Effect Upon the Surroundings of Sites}

\section{in the Northwest Territories and Alberta}

\section{In the Northwest Territories}

Unlike the situation in some other jurisdictions, ${ }^{57}$ the two relevant mechanisms (the Northwest Territories Archaeological Sites Regulations and the Area Development Ordinance) do not give any automatic protection to the surroundings of designated sites.

If vistas adjacent to a heritage site are to be protected, they should be specifically included in the area designated under section 6 of the Archaeological Sites Regulations (assuming the Regulations can be used for that purpose). By the same token, if one were to assume that a

48. Id. at 8. $18(9),(10)$.

49. Id. at s. $18(11)$.

50. Id. at s. 18(12).

51. This power was found in the previous version of the Act, at 8. 18(10); it was repealed by the Alberta Historical Resources Amendment Act, 1978, S.A. 1978, c. 4.

52. Supra n. 32 at 8.19.

53. Id. at 8. 37. Oddly enough, the section does not refer to "Registered Historic Resources" and "Provincial Historic Resources", but rather to "Registered Historic Sites" and "Provincial Historic Sites".

54. Id. at $8.20 .3(\mathrm{c})$

55. It is settled that even ministerial discretion is subject to the purposes for which it was granted to the Minister: see Roncarelli v. Duplessis (1959) S.C.R. 121.

56. As stated by Mr. Justice Gould of the British Columbia Supreme Court in Murray v. Richmond (1978) 7 C.E.L.R. 145 at 146.

57. E.g., the Quebec Cultural Property Act protects all property within a radius of 152 metres (500 feet) of a classified historic site; see art. 1(j). 
"development area" could control demolition, those vistas should be included in the development area and a statement foreseeing their protection in the subsequent land use controls should also be included.

\section{In Alberta}

The Alberta Historical Resources Act does not give automatic protection to the surroundings of designated sites either. Again, it would be necessary to specifically include them in the designating order.

Regulations under the Alberta Planning Act, 1977,58 however, specify that where subdivision approval is being sought, the relevant approving authority must send a copy of the application to the Deputy Minister in charge of the administration of the Alberta Historical Resources Act if the land that is the subject of the application is located within a half-mile of a provincial historic resource. ${ }^{59}$ The subdivision approving authority is, however, required only to "consider" any comment made by the Deputy Minister. ${ }^{60}$

\section{G. Effect Upon Districts in the Northwest Territories}

If one adopts the hypothesis that section 6 of the Northwest Territories Archaeological Sites Regulations empowers the Minister of Indian Affairs and Northern Development to designate buildings for protection one should note that a protected "site" can probably be as small or as large as the Minister chooses. To protect an area under the Regulations, it would be advisable to name every building in the designation order. ${ }^{61}$ Such an order would, however, only protect the area against demolition; it would not protect it against alteration or unsympathetic infill construction.

On the other hand, if one adopted the hypothesis that protection can be granted in "development areas", the only prerequisites for protection of an area would be designation as a "development area" by the commissioner, and a follow-up land use control regulating demolition and infill construction.

As mentioned earlier, neither of these hypotheses has been tested in the Northwest Territories.

\section{H. Effect Upon Districts in Alberta}

1. Ambit

The expressions "historic resource" and "land" are broad in scope: when the province designates an "historic resource" and subjacent land, there is nothing to prevent that designation from covering as large or as small a surface as the Minister chooses. ${ }^{62}$

The Act also refers to the protection of "provincial historic areas". 63 The word "area" is another term which, because it is broad in scope, can

58. S.A. 1977 , c. 89 , as amended.

59. Alta. Reg. 132/78, 8. 6(1)(m).

60. Id. at $8.6(2)$. Some consideration is being given to reducing the radius to 1,000 feet.

61. This is precisely what was done under similar legislation to protect the Gastown and Chinatown areas of Vancouver; see British Columbia Gazette, Feb. 18, 1971.

62. For example, the previous Alberta legislation referred to protection of "sites"; and the word "sites" is arguably more restrictive than the words "resources" or "lands". Despite that problem, the word "site" was broad enough to include districts as well as individual buildings. The Government of Alberta designated a sixty-building "site" (under single ownership) at Bitumount; and the government of British Columbia designated Gastown and Chinatown in Vancouver, as protected "sites" even when those sites included hundreds of buildings under multiple ownership.

63. The Alberta Historical Resources Act, supra n. 32 at 88. 19.1, 19.2. 
presumably apply to as large or as small a surface as the government chooses.

It may be argued that if the legislature drew a distinction between "resources" and "areas" in the Act, it did so because it intended "resources" to refer to individual objects and lots,64 whereas "areas" would refer to districts. That proposition is highly conjectural. If a distinction emerges in practice, it will more likely be for administrative reasons rather than legal ones.

\section{Procedure}

The procedure to designate a "provincial historic area" is not identical to the other forms of designation.

First, the designation is made by the Cabinet and not by the Minister of Culture.65

Secondly, occupants are notified after, not before the designation. It is not the Minister who notifies them, but rather the Registrar of the local Land Titles Office, ${ }^{66}$ who tells them that a memo affecting their property has been filed by the Minister.67 The Minister must, however, send the occupant a copy of the relevant regulation. ${ }^{68}$ Obviously, there is no provision for representations to the Historic Sites Board.

The Cabinet has been empowered to pass regulations to amplify the procedure for this kind of designation. ${ }^{69}$

\section{Effects}

Once the Cabinet has designated a "provincial historic area", the consequences are those which the Cabinet has specified by regulation. For example, the Cabinet can enact regulations to:

Prohibit or regulate and control the use, development or occupation of land or buildings; ${ }^{70}$

Prohibit or regulate and control the demolition, removal, repair, construction or reconstruction of buildings or other things; ${ }^{71}$

Regulate and control the construction, height, location or size of buildings; ${ }^{72}$

Authorize any specified Minister of the Crown, government agency or any other person to approve any particular kind of use, development or occupation of land, or to exempt any particular kind or use, development or occupation from the operation of any provision of the Regulations; ${ }^{73}$

Confer on any specified Minister of the Crown, with or without conditions, any power or duty under the Regulations. ${ }^{74}$

Although these provisions appear sweeping, they are in fact almost identical to the power already vested in the Cabinet under the "special

64. At first glance, this argument appears to be supported by the fact that "resource" is defined, at section $1(\mathrm{~g})$ of the Act, as "any work of nature or of man"; this definition is in the singular. However, this support carries no legal weight: The Alberta Interpretation Act, R.S.A. 1970, 189 , states that "words in the singular include the plural"; see 8. 18(1)(i) of the latter statute. 65. Supra n. 63 at 8. 19.1 .

66. Id. at $8.19 .2(7)$.

67. Id. at s. $19.2(1)$.

68. Id. at 8. 19.2(8).

69. Id. at 8. 19.1 .

70. Id. at s. 19.1(2)(a).

71. Id. at s. 19.1(2)(c).

72. Id. at s. $19.1(2)(f)$.

73. Id. at 8. 19.1(2)(e)

74. Id. at s. $19.1(2)(\mathrm{i})$. 
planning areas" provisions of The Planning Act. ${ }^{75}$ Consequently, interpretations of the latter statute may provide guidance for the interpretation of these powers under the Alberta Historical Resources Act. These provisions of the Planning Act will be discussed later in this article.

\section{Interim Protection}

\section{In the Northwest Territories}

If demolition can be averted by designation under section 6 of the Northwest Territories Archaeological Sites Regulations, such protection would presumably take place immediately upon designation by the Minister of Indian Affairs and Northern Development. Similarly, if sites can be protected within a development area, such protection could take effect immediately upon enactment of the Commissioner's order.

Unlike the legislation of several provinces, ${ }^{76}$ neither of these mechanisms specifically empowers officials to halt work pending study of an allegedly meritorious site. At this point, however, the Historical Resources Ordinance can be most useful. That ordinance empowers the Commissioner to suspend "destruction" of any site, designated or undesignated, until such time as an "adequate investigation, recording and salvage" is made. ${ }^{77}$ There is no reason why this delay cannot be invoked pending more permanent protective measures.

\section{In Alberta}

Some sites face an immediate threat: if the designation process is long and complicated, there is a chance that it will be too late to save the site. The Alberta statute deals with that problem in three ways. First, the Minister can freeze a property by issuing a "Temporary Stop Order".78 The initial freeze is for 15 days, but it can be renewed by the Cabinet for such further periods as it sees fit, if the Cabinet suspects that the property is a possible prospect for designation as a "provincial historic resource". 9 The "aggrieved" party can appeal this freeze to the Alberta Court of Queen's Bench. ${ }^{80}$

A second form of interim protection can be ordered if the Minister of Culture feels that the threat to a site deserves further study. He can order that the alteration or damage be delayed until such time as a proper "assessment" has been carried out ${ }^{81}$ and a report submitted accordingly. ${ }^{82}$ Furthermore, the Minister is granted sweeping powers to order "protective measures" which he considers necessary; ${ }^{33}$ there appears to be no time limit (and almost no other limit) on this power. In fact, the Act states that any license or permit (e.g., a construction or demolition permit) can be suspended until the Minister is satisfied that the appropriate protective

75. Supra n. 58 at 8. 144 et seq. An interesting example of how this kind of power is exercised elsewhere is found in Regulation concerning Historic Districts and Natural Districts, 1973 Quebec Official Gazette II, at 295.

76. E.g., Alberta Historical Resources Act, 8. 35; B.C. Heritage Conservation Act, 8. 7; Quebec Cultutal Property Act, s. 29; Saskatchewan Heritage Act, s. 8.

77. Supra n. 19 at s. $9(1)$.

78. The Alberta Historical Resources Act, supra n. 32 at 8.35.

79. Id. at $\mathrm{s.} 35(2)$.

80. Id. at s. $35(3)$.

81. Id. at $8.22(2)(\mathrm{a})$.

82. Id. at s. $22(2)(\mathrm{b})$.

83. Id. at 8. $22(2)(c)$. 
measures have been carried out. ${ }^{84}$ This appears to leave open the possibility of virtually indefinite protection.

Thirdly, a form of interim protection takes place as soon as the Minister of Culture serves notice upon an owner that the building may be designated as a "Registered Historic Resource" or a "Provincial Historic Resource". Once the notice is served, the property is immediately protected in the same manner as if the designation process had been completed. ${ }^{85}$ This interim protection lasts 120 days unless it is cut short by the Minister ${ }^{86}$ or by the courts. ${ }^{87}$ Naturally, "interim" protection of this variety would also end if replaced by formal designation as a Registered Historic Resource or a Provincial Historic Resource.

\section{J. Applications}

\section{In the Northwest Territories}

Any requests for protection through section 6 of the Northwest Territories Archaeological Sites Regulations can be addressed to the Minister of Indian Affairs and Northern Development.88 Requests for designation of "development areas" can be addressed to the Department of Local Government.89

\section{In Alberta}

Any requests for protection under the Alberta Historical Resources Act should be addressed to the Minister of Culture or to Alberta Culture. ${ }^{90}$

\section{K. Enforcement}

\section{Inspection}

Unlike the statutes of several provinces, ${ }^{91}$ neither the Northwest Territories Archaeological Sites Regulations nor the Historic Resources Ordinance stipulates that heritage sites can be inspected. "It is well settled that without a statutory right of entry on property, it does not exist."92 The Area Development Ordinance does not specify a right of inspection either, but it does say that "The Commissioner may appoint one or more officers for the purpose of administering and enforcing the Ordinance".93 This creates an inference, still untested, that these officials can carry out inspections.

Sites in Alberta which the Minister has reason to believe may qualify as designated sites can be inspected by representatives of the Minister. ${ }^{94}$

\section{Penalties}

Three kinds of penalties are foreseeable for offences.

84. Id. at s. 22(3).

85. Registered Historic Resource: see s. 17(6). Provincial Historic Resource: see s. 18(13).

86. Registered Historic Resources: see s. 17(6). Provincial Historic Resources: see s. 18(3).

87. Registered Historic Resources: see s. 17(7). Provincial Historic Resources: see s. 18(14).

88. Address: D.I.A.N.D., Ottawa, Ontario K1A OH4. However, it is probably expedient to route such application through: The Northwest Territories Heritage Council, $c / o$ The Northern Heritage Centre, Dept. of Natural and Cultural Affairs, Government of the Northwest Territories, Yellowknife, N.W.T., X1A 2L9.

89. Contact: Town Planning and Lands, Department of Local Government, Government of the Northwest Territories, Yellowknife, N.W.T., XOY 1 H0.

90. Alberta Culture, 10004 - 104 Avenue, Edmonton, Alberta, T5J 0K5.

91. E.g., Alberta Historical Resources Act, s. 22; B.C. Heritage Conservation Act, s. 7; Quebec Cultural Property Act, 8. 54; Saskatchewan Heritage Act, s. 8.

92. Rogers, Ian McFee, Canadian Law of Planning \& Zoning 253.

93. Supra n. 27 at 8. 5(1).

94. The Alberta Historical Resources Act, supra n. 32 at s. 22(1). 
The first entails restoration of the situation to the status quo ante through reconstruction, at the owner's expense, of an altered or demolished designated structure. Although this is usually the most satisfactory means of dealing with offences to heritage legislation, and is provided for in some provinces, ${ }^{95}$ restoration is not specifically foreseen in any of the three relevant enactments in the Northwest Territories.

Section 38 of Alberta's Historical Resources Act, on the other hand, provides that reconstruction at the owner's expense can be ordered by the Minister in the case of damage to a Provincial Historic Resource, but not in the case of Registered Historic Resources. The latter are thereby deprived of one of the more effective means of protection.

The second form of penalty is a fine. In the Northwest Territories, offenders against the Area Development Ordinance face a maximum fine of $\$ 200.96$ The fine for offences under other enactments is not stipulated; in the absence of any such stipulation, the maximum fine is $\$ 500$ as set by the Criminal Code. ${ }^{97}$ This amount is lower than that provided in most other jurisdictions. In Alberta, for instance, the maximum amount for offences against the Act is $\$ 50,000.98$

The third form of penalty is a more substantial deterrent, that is, a term of imprisonment. In the Northwest Territories, no imprisonment can be ordered for offences against the Area Development Ordinance; offences under the other two enactments are again covered by the Criminal Code and bring a maximum prison sentence of six months as an alternative to or in addition to a fine. 99 Alberta provides for imprisonment of up to one year instead of or in addition to a fine. ${ }^{100}$

\section{Binding Authority}

The federal government is usually exempt from land use controls in most parts of Canada, and the status of federally-regulated works is the subject of debate. The exempt status of the federal and territorial governments is just as clear in the Northwest Territories, where the Interpretation Ordinance ${ }^{101}$ specifies them to be exempt ${ }^{102}$ from such things as the Historical Resources Ordinance and the Area Development Ordinance. These governments are similarly exempted from the Northwest Territories Archaeological Sites Regulations by section 16 of the federal Interpretation Act.103

In Alberta, it is similarly unclear whether the Historical Resources Act applies to federal lands ${ }^{104}$ or to federally-regulated lands ${ }^{105}$ (for example, railway property). The provincial government, on the other hand, is definitely bound by the Act, ${ }^{106}$ with the exception of certain procedural

95. E.g., Ontario Heritage Act, 1974, s. 69; Quebec Cultural Property Act, s. 57.

96. Supra n. 27 at 8. 7.

97. R.S.C. 1970 , c. C.34, s. $722(1)$.

98. Supra n. 32 at $8.38(1)$.

99. Supra n. 97.

100. Supra n. 32 at s. 39.

101. R.O.N.W.T. 1974, c. I-3.

102. Id. at s. 13.

103. R.S.C. 1970, c. I-23.

104. Supra $\mathrm{n} .1$ at 14.

105. In the latter case, however, jurisprudence leans in favour of provincial jurisdiction: supra $\mathrm{n} .1$ at 16.

106. Supra n. 32 at 8.39. 
aspects. 107 However, if the government were to act illegally, it would be very difficult for citizens to have the law enforced, for reasons outlined later in this article. ${ }^{108}$

\section{THE MUNICIPAL LEVEL}

\section{A. Introduction}

There are two main purposes behind any action to conserve structures and streetscapes: first, to protect valuable buildings against demolition and unsympathetic alteration, and secondly, to maintain the integrity of the scene by discouraging unsympathetic infill construction. The latter purpose is particularly important in the preservation of streetscapes and areas.

\section{B. Planning}

\section{General}

It would undoubtedly be desirable for every community to consider heritage conservation in its planning process. Unlike communities in some jurisdictions both overseas ${ }^{109}$ and in Canada, ${ }^{110}$ the Northwest Territories and Alberta municipalities are currently under no obligation to do so. Although proposals to this effect were advanced in Alberta as far back as 1973,111 such legislative measures have yet to be taken. Municipalities in the Northwest Territories are not even under a legal obligation to prepare a plan of any description unless ordered to do so by the Commissioner. ${ }^{112}$

\section{The Tegon Problem}

Unlike the situation elsewhere, the Alberta Planning Act does not list conservation of buildings and districts or, for that matter, any other possible components of the planning process. The question is therefore open as to whether the conservation of buildings and districts is a legitimate component of "plans" and "planning" at the municipal level.

In the complicated Tegon case, ${ }^{113}$ it was said, inter alia, that such a purpose was not a "planning purpose"."14 That point was not, however,

107. Supra n. 32 at s. 18.2 .

108. See the section of this article entitled "Public Participation".

109. E.g., in the United Kingdom: see the Civic Amenities Act 1967, 8. 1(1).

110. E.g., Manitoba Planning Act, 8. 27(4); City of Winnipeg Act, 8s. 63, 65; New Brunswick Community Planning Act, s. 23(5)(vi)(J).

111. Towards a New Planning Act (Alberta Municipal Affairs, 1973) at 8. 20(4)(g).

112. At section 2 the general purpose of the Act is stated to be: The purpose of this Act and the regulations is to provide means whereby plans and related measures may be prepared and adopted to (a) achieve the orderly, economical and beneficial development and use of land and patterns of human settlement, and (b) maintain and improve the quality of the physical environment within which patterns of human settlement are situated in Alberta, without infringing on the rights of individuals except to the extent that is necessary for the greater public interest. In practice, plans are under way in half the communities: see Land Use Programs, supra n. 17 at 149-150.

113. Re Tegon Developments et al. and Council of the City of Edmonton et al. (1978) 81 D.L.R. (3d) 543 (Alta. S.C.A.D.); appeal to the Supreme Court of Canada dismissed November 30, 1978.

114. In the words of Mr. Justice Moir, speaking for the Supreme Court of Alberta (Appellate Division), "it is not a valid exercise of the (planning) power to use it to preserve historical sites and to induce others to advance money to preserve historical sites. . . . It was not a planning purpose". Id. at 548. 
the deciding issue in the case; ${ }^{115}$ instead, the case was decided upon "remarkable semantic footwork".116 Consequently, it has been argued that the allegation concerning "improper purposes" can be disregarded.117

Furthermore, after the Tegon case was initiated, the Alberta legislature enacted new legislation conferring conservation powers upon municipalities. ${ }^{118}$ It is possible that this legislation would be construed as tacit authority for municipalities to include conservation as a component of the planning process: it appears absurd to grant powers to a government, and then say that the government cannot make plans as to how it will use those powers. Nevertheless, some authorities still suspect that in light of the attitudes of the courts in Alberta, amendments to the Alberta Historical Resources Act would not be construed as authority to draft more comprehensive plans as defined in the Planning Act. This question therefore remains open to uncertainty.

Finally, the Tegon case was criticized as being inconsistent with established jurisprudence and other legal authority. ${ }^{119}$

The Supreme Court of Canada could have decided the issue when Tegon was appealed to that body; instead, the court confined its decision to semantic issues, and thereby left open the question as to whether conservation is a legitimate planning purpose.

This decision was also criticized, ${ }^{20}$ but for the time being, if municipalities in Alberta or the Northwest Territories wish to take action on behalf of the built environment, it would be prudent of them to downplay the "conservation" purpose of their legislation and to emphasize the other planning objectives of such by-laws instead.

\section{Effects of Planning}

The effect of plans in the Northwest Territories is not as clearly defined as in some other jurisdictions. It appears that, unlike plans in other jurisdictions, ${ }^{121}$ a plan would not necessarily commit the municipality to a certain course of legislative action. In other words, the municipality is not compelled to enact by-laws to put all the provisions of the plan into effect.

The extent to which the plan would impede incompatible municipal action is also unclear. It is relatively certain that, in the absence of any statement in the Planning Ordinance ${ }^{122}$ to the contrary, an individual proprietor would not be bound by the plan unless additional by-laws to enforce the plan were in existence.

115. The deciding issue was as follows: Alberta municipalities had been empowered (under old legislation which is now amended) to regulate "use of land" and "special aspects of specific kinds of development". Efforts to protect an historic district were invalid because they fell outside these municipal powers: according to the courts, these efforts did not regulate "use" because they tried to protect buildings regardless of use; and they did not regulate "specific kinds of development" because they regulated all development.

116. See Heritage Canada Magazine, Feb. 1979, at 32.

117. "Some lawyers took the whole declaration about 'improper purposes' with a grain of salt. They argued that it was all superfluous and expendable ('obiter dicta', to use the legal phrase). According to them, the real reason for the judgment was the semantic argument; the rest could be disregarded". Id. at 33 .

118. Alberta Historical Resources Act, supra n. 32 at ss. 19.3, 19.4 and 19.5.

119. Supra n. 1 at 11.

120. Supra n. 116 at 32-34. The article is entitled "In the Wake of the Tegon Mess".

121. E.g., Nova Scotia Planning Act, 8. 33(i).

122. Planning Ordinance, R.O.N.W.T. 1974, c. P-8, as am. 
The municipality would at least be partly bound by the plan because its zoning by-laws would have to be "based" upon the plan (or upon a "survey")122a It is not clear, however, whether other by-laws (e.g., public works by-laws) would be similarly bound: in the absence of the kinds of statutory provisions that exist in other jurisdictions, ${ }^{123}$ there is nothing to prohibit a municipality from undertaking public works contrary to its own plan. The Commissioner may, however, intervene to compel the municipality to respect or enforce a plan. ${ }^{124}$ Consequently, the adoption of a heritage-oriented plan (or a heritage-oriented amendment to the official plan if it already exists) will probably be useful in the long term.

In Alberta, the matter of planning for heritage purposes is important because the Planning Act makes planning compulsory for agglomerations of over 1,000 inhabitants and rural municipalities of over $10,000.125$

Upon adoption of a plan, all municipalities of over 1,000 inhabitants are obliged to enact a "land use by-law",126 but the Alberta statute, unlike legislation of other jurisdictions, ${ }^{127}$ does not specify clearly that the bylaw must implement the plan. Under the previous planning legislation, ${ }^{128}$ by-laws which were not land use controls apparently did not have to coincide with the plan either. Municipalities could, therefore, vote things such as public works projects contrary to the plan; in this respect Alberta again differed from other jurisdictions. ${ }^{129}$ The present Act does not deal with this question.

Similarly, under the old Act, the failure to conform to the plan could be corrected by ministerial intervention. ${ }^{130}$ This right of ministerial intervention has been dropped from the new Planning Act.

Consequently, the drafting of a heritage-oriented plan does not have the same significance in Alberta as it does in some other jurisdictions. Such a plan is neither a prerequisite to further heritage-oriented action nor is it as great a deterrent to unsympathetic municipal action. Nevertheless, a heritage-oriented amendment would be a useful basis for future land use controls and would probably be useful in the long run in other ways as well. Such amendments have already been drafted in other jurisdictions, from which examples are available. ${ }^{131}$

122a. Id. at 8. $15(1)(\mathrm{a})$.

123. E.g., Ontario Planning Act, s. 19(1); P.E.I. Planning Act, s. 35; Manitoba Planning Act, 8. 34(1); B.C. Municipal Act, 8. 698(1).

124. Supra n. 122 at s. $36(1)$.

125. The Planning Act, 1977, supra n. 58 at 8. 59(1).

126. Supra n. 58 at $8.66(1)$.

127. E.g., the Nova Scotia Planning Act, s. 33(1).

128. The Planning Act, R.S.A. 1970, c. 276 (superseded by the Planning Act 1977, proclaimed in April 1978).

129. E.g., British Columbia Municipal Act, R.S.B.C. 1960, c. 255, s. 698(1); Ontario Planning Act, R.S.O. 1970, s. 19(1).

130. The Planning Act, R.S.A. 1970, s. 142.

131. E.g., a number of useful precedents are on file at the Ontario Heritage Foundation, 77 Bloor Street (7th Floor), Toronto M7A 2R9. The legal effect on such plans in Ontario is described by John Swaigen of the Canadian Environmental Law Association: "if a municipality made an official plan for an area to be designated as a heritage conservation area, the municipal council would be acting illegally if it tried to construct public works, and the construction required the demolition of designated heritage properties. Whether the municipality would be acting illegally if it built public works which simply detracted aesthetically from the area would probably depend on the exact wording of the official plan, the testimony of experts, and many other factors". Opinion rendered to Heritage Canada, July 25, 1977. Unpublished. 
One partial exception concerning the binding character of plans is the regional plan. This is a plan adopted by a regional planning commission, representing a number of municipalities. All by-laws must be consistent with such a plan. ${ }^{132}$

\section{General Format of Land Use Controls in Alberta}

Land use controls in Alberta may be of two basic types: zoning or development control. The former implies the passage of a zoning by-law, which explains precisely what the owner can do with his property; traditionally, everything is permitted unless specifically prohibited by the by-law.132a Development control is the reverse: in a development control area, no development is permitted unless it is specifically approved by officials on a discretionary basis.

Alberta's new Act has replaced interim and permanent development controls with a land use by-law. ${ }^{133} \mathrm{~A}$ land use by-law may, however, establish within a municipality what is called a "direct control district". ${ }^{134}$ The council appears to have a considerable discretion in the control it chooses in such a district. ${ }^{135}$

\section{Controlling Demolition and Alteration}

\section{Governmental Demolition}

This article described earlier the system of "environmental impact assessments". ${ }^{136}$ As mentioned, some jurisdictions use this system to protect the built environment; while Alberta has legislation which could achieve identical results, this objective has not been pursued in Alberta except for archaeological sites. The Northwest Territories have no such legislation.

Alberta municipalities could be subjected to this environmental impact assessment system; and if this were done to protect the built environment, municipalities would have to file satisfactory environmental impact assessments before destroying major components of heritage in the community. The legislation is in place to create such a situation, but Alberta has not yet put it into effect for that purpose.

\section{Other Demolition in the Northwest Territories}

Municipal powers to control demolition in the Northwest Territories are not worded as clearly as those which exist in other jurisdictions to protect heritage buildings either permanently ${ }^{137}$ or temporarily. ${ }^{138}$ Nevertheless, the Planning Ordinance appears to confer such powers. Under section 19(a), a "zoning by-law may ... prohibit ... the alteration, repair, removal or demolition of a building". This wording

132. The Planning Act 1977, supra n. 58 at s. 53(1).

132a. This stance has, of course, been modified by practice: municipalities usually prohibit all uses which are not specifically listed. This practice is confirmed by sections 67 to 69 of the Planning Act, 1977 particularly at 69(1), which envisages permits only for those uses which are specifically listed in the by-law.

133. Id. at s. 67.

134. Id. at s. $67(3)(16)$.

135. Id. at s. 68. See also Rogers, supra n. 92, 1978 Supplement, at 48.

136. See "Early Warning System, etc." earlier in this article.

137. E.g., British Columbia Heritage Conservation Act, Part III; City of Winnipeg Act, s. 483(c); City of Charlottetown Act, c. 36; City of St. John's Act, s. 367A; New Brunswick Municipal Heritage Preservation Act, 8. 5 et seq.

138. E.g., Quebec Cities \& Towns Act, art. 426(1)(d); Ontario Heritage Act 1974, Part IV. 
differs from the enabling legislation of most other Canadian jurisdictions and the general phrasing does not indicate whether it was intended for heritage conservation purposes. Indeed, its application to such purposes appears extremely rare. Nevertheless, the wording does create the unavoidable inference that municipalities can enact zoning by-laws which prohibit demolition.

If a municipality should decide to avail itself of this apparent power to control alteration and demolition, the next question will concern the scope of such a "zoning by-law". A zoning by-law applicable to a group of buildings (e.g., a "heritage area") would probably not contradict the criteria for validity of zoning by-laws. On the other hand, a zoning by-law prohibiting alteration or demolition on only one or two lots could be attacked as "spot zoning". Such zoning of one or two lots has had a checkered career in Canadian courts, and should probably be regarded as very hazardous. ${ }^{139}$

\section{Other Demolition in Alberta}

As far back as 1973, it was proposed that municipalities be allowed to protect historic sites and areas against alteration and demolition. ${ }^{140}$ These provisions were enacted in revisions to the Alberta Historical Resources Act in 1978.141 Municipalities could henceforth designate buildings for permanent protection.

There was a long delay in proclaiming these provisions in effect. The reason why these provisions were not enforced may be as follows.

Sections 19.3 and 19.4 grant specific powers to municipalities to protect sites and districts, but section 19.5 makes that protection contingent upon "compensation". According to some texts, experience in other provinces proves that such a requirement would stifle the municipal power, since few municipalities have sufficiently large budgets to take on designations with compensation. ${ }^{142}$

Conservationists were therefore reluctant to press for the proclamation of these sections of the Alberta Historical Resources Act. Furthermore, they have expressed the argument that the protection of worthy districts should, in principle, be a component of "planning" and hence be in the Planning Act instead of the Alberta Historical Resources Act. ${ }^{143}$ That leads to the question of whether mechanisms under the Planning Act (which require no compensation) can be used to protect sites and districts against demolition.

It is not clear whether Alberta municipalities can use their zoning power to prohibit demolition only for purposes of public safety, or whether they can prohibit demolition for other reasons as well (heritage

139. See Rogers, supra n. 92 at 156.4. Rogers cites two Ontario cases which appear to favour spot zoning; however, jurisprudence still appears unsettled.

140. Towards a New Planning Act, supra n. 111 at ss. $32,33$.

141. See 88. 19.3, 19.4 and 19.5 of that Act.

142. Of the seven provinces which currently empower municipalities to protect sites, only one (British Columbia) states that such a by-law is predicated upon compensation; in that province, "the worthy goal of financial assistance to heritage properties has been turned into a deterrent to the protection of the province's heritage". See Heritage Fights Back by this writer (Heritage Canada and Fitzhenry \& Whiteside, Ottawa, 1978) at 162.

143. This is so despite the setback of the Tegon case, supra n. 113. That case affected Edmonton's Strathcona district; nevertheless, "conservationists in Strathcona are confident that the new version of the Planning Act will suffice to sustain protective measures in Strathcona". Heritage Canada magazine, Feb. 1979, at 34. 
conservation, for example). The Planning Act states that: "A land use bylaw may prohibit or regulate and control the use and development of land and buildings within the municipality",144 and that a "land use by-law may provide for ... the enlargement, alteration, repair or removal or relocation of buildings". ${ }^{145}$ The question thus arises: if this power is given for reasons of safety only, why does the section empower municipalities not only to regulate the "removal" of buildings, but also to prohibit it? Since the prohibition on demolition has no conceivable connection with public safety, it would appear that municipalities can exercise that power for other purposes, such as the designation of protected heritage zones.

Theoretically, a municipality could attempt to control demolition through an alternative device. Municipalities can stipulate that in specific areas certain uses are "conditional",146 that is, are subject to the discretion of the authorities. A municipality could conceivably declare that development in a given zone could proceed only on the condition that the development did not replace a structure of a certain class (for example, a designated structure). No such by-law has ever been attempted in Alberta, however, and one can predict with relative certainty that the owner affected would challenge its legal validity. The outcome is uncertain.

A third approach (though not, strictly speaking, a municipal power) may be found in the "special planning areas" which section 144 of the new Act contemplates.146a These areas resemble the "provincial historic areas" described in the Alberta Historical Resources Act. In any such area the provincial government may, by regulation, "prohibit or regulate and control the use, development or occupation of land or buildings"147 and "prohibit or regulate and control the demolition, removal, repair, reconstruction or construction of buildings or other things", 148 as well as "regulate and control the construction, height, location or size of buildings". ${ }^{149}$ The wording of the section seems to be broad enough to cover regulation for heritage purposes in such a planning area.

Finally, a fourth device may be found in the "direct control" system established by section 68. This system empowers municipalities to designate an area in which the municipal council will regulate and control development in such manner as it considers necessary.

If demolition is deemed to be a form of development, it follows that a municipality may decide that no demolition could take place in such an area without permission. Unlike some statutes elsewhere, ${ }^{150}$ however, the Alberta Planning Act does not specifically include demolition in the definition of development. ${ }^{151}$ The fact that demolition appears to

144. The Planning Act 1977, supra n. 58 at s. 67(1).

145. Id. at s. $67(3)(10)$.

146. Id. at 88. 67,69 .

146a. It is nevertheless the opion of some observers that the government is unlikely to use this mechanism: if comparable powers exist under section 19.1 of the Alberta Historical Resources Act, it is believed that the latter statute would be used instead. The latter mechanism, like section 144, does not require compensation; nevertheless, it is this writer's view that because Planning Act mechanisms continue, in general, to be more familiar both to the government and to the public, there may be policy reasons to continue considering the section 144 mechanism as a plausible alternative to section 19.1 of the Alberta Historical Resources Act.

147. The Planning Act 1977, s. 144(2)(a).

148. Id. at s. $144(2)(\mathrm{c})$.

149. Id. at s. $144(2)(\mathrm{g})$.

150. E.g., the New Brunswick Community Planning Act, R.S.N.B. 1973, c. C-12, s. 1.

151. The Planning Act 1977, s. 1(5). 
constitute a drastic change in the "use" or "intensity of use" of a building creates the inference that demolition is indeed a form of development. If this hypothesis were true, then demolition could be controlled in a direct control area. The hypothesis was challenged, however, in the Tegon case, ${ }^{152}$ and although the courts fell short of declaring that demolition was not a form of development, the hypothesis is most uncertain, and thus it is equally uncertain whether demolition can be so controlled under "direct control".

\section{E. Controlling Infill Construction}

\section{General}

In Alberta, infill construction can be controlled under three basic systems: direct control, special planning areas, and zoning. The first two methods are fairly sweeping; the third is divided into a number of individual components which will be described in turn. In the Northwest Territories, construction can be controlled through zoning.

As mentioned earlier, one important feature to consider whenever discussing municipal powers (except those proposed in the Alberta Historical Resources Act) is that they are usually exercised over a wide area, not over a single lot. If a municipality tries to pass a by-law affecting a single lot, the effort is not necessarily illegal, 153 but it is nevertheless regarded by the courts with suspicion. If there is any hint of discriminatory treatment, the courts may invalidate the by-law; this can occur even when the by-law ostensibly applies to a wider area. ${ }^{154}$

\section{Direct Control in Alberta}

Since construction and alteration of all kinds is included in the definition of "development", no such work can be undertaken in a direct control area unless approved by municipal authorities. ${ }^{155}$

\section{Special Planning Areas in Alberta}

In these areas the province has jurisdiction over the demolition, removal, repair, reconstruction, and construction of buildings. ${ }^{156}$

\section{Size and Height Controls in Zoning}

For two reasons, size and height controls are found in almost every attempt to preserve the character of neighbourhoods: first and foremost,

152. The Tegon case mentioned supra $\mathrm{n} .113$ held that the protection of a building was irrelevant to "use" since it attempted to protect buildings "regardless of use"; the argument that protection pertained to the "intensity of use" of a building was not considered in the reasons for judgment. This judgment has been criticized as "semantic acrobatics": Heritage Canada magazine, Feb. 1979, at 32.

153. "The new Alberta Act makes this clear by directing the council in its by-law to divide the municipality into districts of such number and area 'as the council considers appropriate' (the Planning Act, 1977, s. 67(2)(a) )". Rogers, supra n. 92, Supp. to 1978 at 50. In the same text, Rogers further states (at 156.4) that "a by-law which is limited in its application to one parcel of land owned by one person has been upheld". His authority is Re North York, 24 D.L.R. (2d) 12 (Ont. C.A.). See also Scarborough v. Bondi, (1950) S.C.R. 444, 18 D.L.R. (2d) 161.

154. An interesting example of the problems which can result from an awkward attempt to protect a single heritage site through zoning is Re H. G. Winton Ltd. and Borough of North York (1978), 20 O.R. (2d) 745. In the words of the court: "If Council deems the property of sufficient historical or other value to deserve special treatment for its preservation, there are no doubt ways it may properly and fairly proceed to effect its intention. But it is not entitled to rezone this one spot on the entire map of North York to do so. This is simply spot zoning calculated to defeat existing land use rights; it represents unfair and unequal treatment. It is a discriminatory use of the zoning power." (at 745).

155. The Planning Act 1977, 8. 68.

156. Id. at 8. 144. 
the size of a building has a definite impact upon its environment, since an oversize building will appear incompatible with its environment regardless of its architectural style. Secondly, a restrictive size and height by-law can indirectly discourage unwanted redevelopment.

Alberta and Northwest Territories municipalities are empowered to control the height and size of buildings. ${ }^{157}$

In several American jurisdictions, a new kind of height control, which is both precise and flexible, has been developed. The permitted height of a building is expressed as a percentage (for example, not less than $80 \%$ and not more than 120\%) of the average height of buildings on the block, or of the buildings fronting upon the street and built before 1950. Although a different permissible height on each block may be the result, this kind of control is not, strictly speaking, spot zoning because it is of general application throughout the area. It could be useful in communities which already have a slightly irregular roof line. However, whether it would be upheld in Alberta and the Northwest Territories still remains to be seen.

\section{Design Control Through Zoning}

The municipalities of Alberta and the Northwest Territories are also empowered to regulate the "design, character and appearance" of buildings. ${ }^{158}$ This provision does not, however, confer discretion upon the municipality to accept or reject designs as it pleases. Rather, it foresees regulation by by-law; that is, acceptable designs must be spelled out in the by-law itself. If they are not, the by-law can be quashed for uncertainty. ${ }^{159}$ This requirement of precision can lead to problems, since it necessarily inhibits flexibility. Consequently, architectural controls usually generate some opposition from builders and architects, who resent limitations upon their creativity. The importance of such controls to the character of streetscapes and areas, however, remains undiminished.

For further information concerning the format of such by-laws, Heritage Canada should be contacted. ${ }^{160}$

\section{Use Zoning}

Municipalities are empowered to regulate the uses to which property can be put. ${ }^{161}$ The decision to preserve an area does not usually imply a change of use. It is customary to retain the existing zoning designation and simply add extra conditions to protect the special features of the area.

Some care must be exercised, however, to ensure that the zoning is not so loose as to encourage displacement of the population. For example, residential heritage areas are sometimes vulnerable to an invasion of bars, restaurants and discotheques, which can have an unsettling effect upon the neighbourhood. If the neighbourhood character is to be maintained, use zoning must take account of this effect.

It is customary in other jurisdictions to make only minor modifications in the use zoning by-law applicable to valuable areas. For example, one

157. Id. at s. 67(3)(2); N.W.T. Planning Ordinance, s. 16(1)(a)(i); N.W.T. Municipal Ordinance, s. $192(1)(d)$.

158. The Alberta Planning Act, 1977 at s. 67(3)(7); the N.W.T. Planning Ordinance at s. 16(1((a)(v).

159. Re Mississuaga Golf \& Country Club Ltd., 40 D.L.R. (2d) 673. Although the case was decided in Ontario, an Alberta court could well reach the same conclusion.

160. Heritage Canada, P.O. Box 1358, Station B, Ottawa, Ontario, K1P 5R4.

161. Alberta Planning Act 1977 at 8. 69(1)(a); N.W.T. Planning Ordinance at 8. 14(b); Municipal Ordinance at $8.192(1)(c)$. 
may see a prohibition on service stations, wholesale outlets or the like. It should be remembered, however, that no such by-law can have retroactive effect. Consequently, any regulation to exclude such uses from the area would have the effect of "freezing" such installations at the number that existed at the time of the passing of the by-law.

It is unlikely that the regulation of use can be extended to the point of freezing certain lands altogether. For example, the zoning of land as "recreational" or "historical" probably cannot impede other kinds of construction. Despite the fact that several communities attempt to use this "zoning" to freeze land, the practice has run into trouble in the courts. ${ }^{162}$

\section{Set-Back Zoning}

Set-back rules are those which dictate the proper distance between a building and the street. They are important for the harmonious appearance of a streetscape. Location of buildings can be regulated by municipalities in Alberta and the Northwest Territories. ${ }^{163}$

Some cities are currently considering adapting the $80-120 \%$ formula to set-backs, that is, by stating that the set-back cannot be less than $80 \%$ nor more than $120 \%$ of the average set-back of other buildings on certain streets. This approach is suitable for streets where set-back is already irregular. The formula is still untested.

\section{F. Signs}

Signs can be regulated by municipalities in both Alberta and the Northwest Territories. ${ }^{164}$ Regulation is essential to the maintenance of a "heritage area", since any outdoor advertising has a significant impact upon the area's appearance. Again, precision is required-see, for example, the Gastown Sign Guidelines, available from the Central Area Division of the Vancouver City Planning Department. ${ }^{165}$

\section{G. Trees and Landscaping}

Trees and landscaping also enhance the appearance of a heritage area. Municipalities in most jurisdictions are given power to control the destruction of trees. ${ }^{166}$ Other shrubs are sometimes also included. ${ }^{167}$ The Northwest Territories represent an exception: although the Planning Ordinance empowers municipalities to limit the height of trees and shrubs ${ }^{168}$ or to remove them, it says nothing about their protection. Without such a provision, it is unlikely that such a power over trees and shrubs can be inferred, ${ }^{169}$ unless the appearance of the greenery becomes so bad that it constitutes a nuisance.

162. See Sula v. Duvernay (1970) Que. C.A. 234, where the Quebec Court of Appeal invalidated zoning as a "park". See also: Re District of North Vancouver Zoning By-law 4277 (1973) 2 W.W.R. 260 and Regina Auto Court v. Regina (1958) 25 W.W.R. 167.

163. Alberta Planning Act 1977 at s. 67(3)(2); N.W.T. Planning Ordinance at 8. 16(1)(a)(iii); N.W.T. Municipal Ordinance at s. 192(1)(e).

164. Alberta Planning Act 1977 at s. 67(3)(13), (14); N.W.T. Planning Ordinance at s. 16(1)(a)(ix); N.W.T. Municipal Ordinance at 88. $183(1)(\mathrm{a})$ and $192(1)(\mathrm{g})$.

165. British Columbia Gazette, February 18, 1971.

166. In some places, proprietors can even be compelled to plant trees and conduct landscaping. e.g., Quebec Cities and Towns Act, art. 429(36).

167. E.g., British Columbia Municipal Act, s. 514(1)(e); Manitoba Planning Act, s. 41(2)(o), 41(2)(e); New Brunswick Community Planning Act, 8. 34(3)(a)(vii); Quebec Cities and Towns Act, 8. 429(36).

168. Planning Ordinance, s. 16(a)(iv).

169. Re Mississauga Golf \& Country Club Ltd., supra n. 159. 
The new Alberta Planning Act, 1977 makes only one reference to this issue: a municipality is allowed to regulate "the landscaping of land or buildings". ${ }^{170}$ Unlike municipalities in other jurisdictions, ${ }^{171}$ Alberta municipalities cannot go to the extent of compelling a proprietor to landscape his property.

Examples of a model tree by-law are currently available from the Canadian Environmental Law, Association. ${ }^{172}$

\section{H. Fences and Walls}

Theoretically, fences and walls could be included in the definition of "building",173 and consequently might be regulated in the same manner as buildings. Most jurisdictions, however, confer special powers regarding walls and fences, including the power to compel owners to fence certain lands. ${ }^{174}$ The new Alberta statute, while it does provide for the regulation of "the location, height and maintenance of fences and walls", 175 does not give a municipality power to compel installation, for example, around parking lots.

The Northwest Territories Planning Ordinance allows for the regulation of the height $t^{176}$ of fences and walls; and where regulation is necessary to maintain the safe movement of traffic, municipalities can enforce "placement, height and maintenance". ${ }^{177}$

\section{Maintenance}

Maintenance is obviously essential to retain the quality of an area. Alberta municipalities are given general power to "establish and enforce minimum standards" for the maintenance and occupancy of property. ${ }^{178}$ These standards appear to be applicable to all property: The Municipal Government Act makes no distinction between residential and nonresidential property, and in the absence of any suggestion to the contrary, maintenance appears compellable for the exterior as well as the interior of buildings. Municipalities in the Northwest Territories are also given power to regulate the maintenance of buildings. ${ }^{179}$ Again, the Ordinance makes no distinction between residential and non-residential property.

Examples of such by-laws are available from housing authorities. ${ }^{180}$

It should be noted, however, that maintenance and occupancy standards must occasionally be approached with caution. There have been frequent occasions on which the standards enacted have been so strict that there was no way for the owners of older buildings to meet them without costly renovations. ${ }^{181}$ Consequently, "provisions such as

170. Planning Act 1977 at 8. 67(3)(4).

171. E.g., Quebec Cities and Towns Act, art. 426(1).

172. 8 York Street, Toronto, Ontario, M5J 1R2.

173. The Planning Act 1977, s. 1.3; Planning Ordinance, s. 2(b).

174. E.g., Nova Scotia Towns Act, R.S.N.S. 1967, c. 309, s. 160; Newfoundland Local Government Act, R.S. 1970 , c. 216 , 8. 98(1)(q); Prince Edward Island Town Act, R.S.P.E.I. 1974, c. T-4, 8. 70(n.1); British Columbia Municipal Act, R.S.B.C. 1960, c. 255, s. 514.

175. Planning Act 1977 , s. 67(3)(5).

176. Planning Ordinance at 8. $16(1)(a)(i)$.

177. Id. at $8.16(1)(a)(i v)$.

178. Municipal Government Act, R.S.A. 1970, c. 246, as amended, at s. $239(1)$.

179. Supra n. 176 at s. 16(1)(iii).

180. For example, one may contact: Residential Rehabilitation Assistance Program (R.R.A.P.), Canada Mortgage and Housing Corporation, Montreal Road, Ottawa, Ontario, K1A OP7.

181. For example, in a recent Ontario case, George Sebok Real Estate Ltd. and David E. Marlow v. The Corporation of the City of Woodstock, the Court of Appeal held that a by-law passed 
[typical maintenance and occupancy standards] often refer to modern building code standards which often do not recognize the special construction problems involved in restoration work ... accordingly, some of these provisions may even prove counterproductive". ${ }^{182}$

\section{J. Interim Control on Construction}

A difficult situation can arise when someone proposes the kind of project which the municipality has been preparing to prohibit, but for which a by-law is not yet ready. In order to maintain the status quo pending the enactment of appropriate controls, municipalities sometimes attempt to enact a "holding by-law", that is, a temporary freeze on development. Under previous legislation, Alberta municipalities could freeze development pending the preparation or adoption of a plan, once appropriate ministerial approval had been received. ${ }^{183}$ This provision appears to have been eliminated. As for the situation where a plan has been adopted, it is not clear whether development can be "frozen" by any mechanism short of immediately declaring an area a direct control area.

Unlike some other provinces, ${ }^{184}$ neither the Northwest Territories nor Alberta has empowered its municipalities to refuse issue of a building permit pending adoption of a by-law, in the absence of any existing bylaw. It is hard to say, however, whether they can pass a holding by-law and thereafter refuse any permits until a further zoning by-law is passed. When first tested in the courts, such a by-law appeared invalid, 185 but more recent cases suggest a carefully worded holding by-law might be possible. ${ }^{186}$

\section{K. Intervention by Higher Authorities}

"In several provinces, the central planning authority or the responsible Minister is empowered to compel the Council to adopt plans and bylaws or to conform to and enforce plans and by-laws that have already been adopted where there has been a failure to do so."187 In the Northwest Territories, this power is conferred upon the Commissioner, who may exercise the powers of a municipal council when the council fails to take appropriate action. ${ }^{188}$ In Alberta, the Minister of Municipal Affairs could do so until $1978,,^{189}$ but that power has since been abolished.

\section{Compensation}

More than one province has had to deal with the thorny question of

under s. 36 of the Planning Act and "prescribing standards for the maintenance of physical conditions and for the occupancy of property" could call for thicker walls, new walls in the attic, more exits, and an improved basement floor-that is, for extensive alterations entailing substantial expenditure of money. The court held that such provisions fell within the ambit of standards for the "occupancy" of property because such standards are higher than those for the maintenance of property. From the point of view of heritage conservation, however, such a high standard may prove to be an incentive for the owner to demolish the building concerned.

182. Opinion of Connie Peterson Giller, Assistant Solicitor for the Regional Municipality of Waterloo (Ontario), Aug. 18, 1977. Unpublished.

183. Planning Act, supra n. 128 at 8. 100(1).

184. E.g., the British Columbia Municipal Act at s. 707(1).

185. Verdun v. Sun Oil Co. (1952) 1 S.C.R. 222; Outrement v. Protestant School Trustees (1952) 2 S.C.R. 506; Ste. Agathe v. Reid (1904) 26 R.C.S. 379.

186. Re Kerr and Brock (1968) 69 D.L.R. (2d) 644. Although these cases were decided in Ontario, it would be open to an Alberta court to reach the same decision.

187. Rogers, supra n. 92 at 252.

188. Planning Ordinance, s. 36(2).

189. Planning Act, R.S.A. 1970, 8. 142. 
whether or not an owner or occupier or other person having an interest in real property, which is the object of protective municipal action, can claim "compensation" from the municipality that made the designation, downzoned the property, or took other such measures.

As mentioned earlier, the problem became very visible when the question arose as to whether Alberta would proclaim into effect certain municipal powers for heritage designation under sections 19.3, 19.4, and 19.5 of the Alberta Historical Resources Act. Section 19.5 provides that:

If a by-law under section 19.3 or 19.4 [allowing for designation] decreases the economic value of a building, structure or land that is within the area designated by the by-law, the council shall by by-law provide the owner of that building, structure or land with compensation for the decrease in economic value.

The fear is, of course, that a municipality will not designate at all if it has to pay compensation for such designation. ${ }^{190}$

That settles the question for that kind of action. It is still necessary to consider the matter of "compensation" for other municipal initiatives, such as zoning and planning measures.

As far as action under the Alberta Planning Act, 1977 is concerned, section 4 is quite conclusive:

Except as provided in this Act, nothing in this Act or the Regulations or in any regional plan, statutory plan, replotting scheme or land use by-law gives a person a right to compensation.

In the Northwest Territories, the matter arises less directly. The only statute which would entitle an owner to compensation would be the (federal) Expropriation Act.191 The owner would have to argue that designation is tantamount to expropriation, or, alternatively, that designation has resulted in "injurious affection". "Injurious affection" is damage to the value of land when a part of the owner's enjoyment of it is lost because of government action.

Both expropriation and injurious affection give an owner the right to demand compensation. Section 23 of the federal Act states:

The compensation money agreed upon or adjudged for any land or property acquired or taken for or injuriously affected by the construction of any public work stands in the stead of such land or property. ...

As far as expropriation is concerned, since designation does not involve the acquiring or taking of land, it would be virtually impossible for a court to equate designation with expropriation.

The question of injurious affection is slightly more complex. In the first place, are we dealing here with a "public work"? In the second place, can it be said that the damage flows from the "construction" of such a work? Again it would appear that no claim can result from the heritage designation.

Finally, action taken by a municipality under the Municipal Ordinance or the Planning Ordinance does not lead to a claim for compensation unless the zoning is being used for improper purposes, such

190. In private correspondence, this writer received the following indicative comment from one Alberta municipality: "We would recommend never to designate, but instead to purchase outright. Why designate and pay compensation without obtaining title?" If followed, this advice would virtually reduce municipal designation to a dead letter.

191. Expropriation Act, R.S.C. 1969-70, c. 41. 
as a municipal attempt to reduce property value prior to an expropriation. ${ }^{192}$

Instead of providing for elaborate compensation at the provincial and municipal levels, proposals have been made to provide incentives through the federal Income Tax Act. ${ }^{193}$ These recommendations would assist the renovation of all existing investment property (e.g., rental property, business property, etc.). They would also provide preferential tax treatment for the owners of designated historic property. ${ }^{194}$ These proposals are currently under study.

\section{Variances}

There are occasions when a municipal zoning by-law inadvertently causes hardship to owners of buildings which it was not intended to affect. Some jurisdictions therefore empower municipalities (or some other body) to exempt these buildings from the application of the by-law; ${ }^{195}$ these exemptions are usually called "variances".

In the Northwest Territories, municipalities with zoning by-laws must establish an "appeal board".196 This appeal board may vary the decision of the municipality respecting the issue of permits to developed property.197 In Alberta, the Planning Act provides that a "development appeal board" shall be established by a municipality having a population of 1,000 or more and may be established by one having a population of less than 1,000.198 Where a board is not constituted, the council of the municipality will serve as the board. The board can, within limits, alter the application of the land use by-law or land use regulation if the development in question does not conflict with the by-law and would not interfere with the neighbourhood and neighbouring properties. ${ }^{199}$

\section{N. Enforcement}

\section{Inspection}

In the Northwest Territories, municipal officials are empowered to inspect sites to help in the preparation of a plan or by-law and to assure compliance with the by-laws. ${ }^{200}$ Municipal officials in Alberta are empowered to inspect sites for the latter purpose. ${ }^{201}$

\section{Penalties}

Three kinds of penalties are usually possible for offences. The first is the obligation to restore a site to what it was before the infraction occurred. Although a municipal council in the N.W.T. may compel "alteration" of a structure to which something illegal has been done, ${ }^{202}$ it is unlikely that this power would extend to the reconstruction of a

192. An extensive discussion of such purposes is found in Rogers, supra n. 92 at 122.6.

193. S.C. 1970-71-72, c. 63 as amended.

194. See Heritage Canada magazine, April 1979. A detailed description of the proposals currently being debated is found in "Current Tax Proposals Affecting Renovation", by this writer, in Second Canadian Building Congress (National Research Council, Ottawa, 1980).

195. See Rogers, supra n. 92 at 183 et seq.

196. Planning Ordinance, 8. 22(1).

197. Planning Ordinance, s. 23(5)(a).

198. Planning Act 1977 at s. 33.

199. Id. at 8. 83 .

200. Planning Ordinance at s. 32(1).

201. Supra n. 198 at s. 43.

202. Planning Ordinance at $8.21(1)$. 
structure which has been illegally demolished. Nor are Alberta municipalities, unlike municipalities elsewhere, ${ }^{203}$ empowered to order a proprietor to restore a building which has been illegally altered or demolished. On the other hand, municipalities in both jurisdictions can order that a structure which was illegally erected be demolished.204

Furthermore, it is possible in the N.W.T. to compel repair of dilapidated premises. ${ }^{205}$ Finally, an Alberta court may, in addition to any other penalty, order a person to comply with the Planning Act, 1977, any regulation thereunder, a development permit, subdivision approval, or any condition attached to them. ${ }^{206}$

A second form of penalty is a fine. In the Northwest Territories, the maximum fine which can be imposed for illegal demolition (or any other by-law offence) is $\$ 500$; continuing offences can result in an additional fine of $\$ 100$ per day. ${ }^{207}$ Offenders against the Alberta Planning Act can be fined,208 the maximum, as stated in the summary convictions sections of the Criminal Code, is $\$ 500 .{ }^{209}$ Offenders against provisions of the Alberta Historical Resources Act face a fine up to $\$ 50,000.209$ a

A third deterrent is imprisonment. Both Alberta and the Northwest Territories, unlike jurisdictions elsewhere, ${ }^{210}$ impose imprisonment only upon default of payment of a fine, ${ }^{211}$ except in the case of offenses against the Alberta Historical Resources Act, which can result in imprisonment for one year.211a

\section{Binding Authority}

As mentioned earlier, 212 the applicability of non-federal regulations (including municipal by-laws) to federal and federally-regulated works has been the object of considerable recent jurisprudence, which may be applicable in certain limited circumstances.

Unlike the situation elsewhere, ${ }^{213}$ neither the Alberta Planning Act, 1977 nor the Alberta Historical Resources Act appear to subject provincial works to municipal by-laws. 213 a Similarly, municipalities in the Northwest Territories cannot create land use controls which are binding upon works of the territorial government. In the absence of any statutory

203. E.g. Ontario Heritage Act, s. 69; Manitoba Planning Act, s. 81(3); City of Winnipeg Act, s. 646(1).

204. Alberta Planning Act 1977, s. 79; N.W.T. Planning Ordinance, s. 21(3). In Alberta, an even more effective provision appears to be section 405 of the Municipal Government Act, supra n. 97 , referring more specifically to demolition.

205. See Environmental Protection Ordinance, 1974 R.O.N.W.T., c. E-3.

206. Supra n. 198 at 8. 149. Section 405 of the Municipal Government Act should again be considered as a possible alternative. Otherwise, it should be noted that, according to some observers, the power conferred upon a Provincial Court judge is difficult to reconcile with the Judicature Act: this could lead a person accused of disregarding an order to argue that the order was not properly issued. Although the exact status of such an order is unclear, it may be more prudent to avoid such a potential controversy.

207. Planning Ordinance, 8. 34(1).

208. Supra n. 198 at s. 148.

209. Criminal Code, supra n. 97 at s. $722(1)$.

209a. Alberta Historical Resources Act, 8. 38(1).

210. E.g., Manitoba Planning Act, s. 81(1); City of Winnipeg Act, s. 138(1).

211. The Planning Act 1977 at s. 148; Planning Ordinance at s. 34(1).

211a. Alberta Historical Resources Act at s. 38(1).

212. Supra in. 9.

213. E.g., New Brunswick Community Planning Act, s8. 18(2), 27; New Brunswick Municipal Heritage Preservation Act, s. 2(2).

213a. The latter statute even specifically excludes the Crown; see s. 39 . 
authority to the contrary, "municipal by-laws do not apply to the Crown",214 that is, to provincial, territorial or federal governments.

Are municipalities bound by their own plans and by-laws? As far as by-laws are concerned, "the new Alberta Act prohibits any local authority from enacting any by-law or authorizing or undertaking any development that is inconsistent with the regional plan".215

Northwest Territories municipalities are partly bound by their plans: their zoning by-laws must be "based" upon their plan.216 Still, it is unclear whether other kinds of by-laws (e.g., authorizing public works) would also be bound by the plan. Unlike legislation in other jurisdictions, ${ }^{217}$ the Planning Ordinance does not specifically prohibit other by-laws which contradict the plan; consequently, the citizen has no clear right to challenge such by-laws on that basis. The Commissioner may, however, intervene in such cases. ${ }^{218}$

As far as by-laws are concerned, it appears that municipalities are bound by their own by-laws; they can, however, formally exempt themselves from their operation. ${ }^{219}$

\section{THE PRIVATE LEVEL: CONSERVATION BY CONTRACT}

\section{A. General}

If a proprietor is willing to subject his property to control on alteration and demolition, it is possible to sign a private agreement with him to that effect. Most agreements are simple contracts: they bind the signatories, but they do not bind anyone else. Consequently, if an owner agrees to protect his property against demolition and later sells the property, the agreement would usually not be binding upon the future owner. Conservationists would find this situation unsuitable in the majority of situations. Fortunately, a special form of agreement is possible to deal with that problem: an "easement" or "covenant" binds future owners as well as the present owners.

\section{B. Easements and Restrictive Covenants}

\section{Contents}

Easements and restrictive covenants are contractual agreements which prohibit the owner of land from doing something on his land (the "servient tenement"). ${ }^{220}$

214. Rogers, supra n. 92 at 143.

215. Id., 1978 Cumulative Supplement at 29.

216. Planning Ordinance, s. 15(1)(a).

217. E.g., Ontario Planning Act, s. 19(1); P.E.I. Planning Act, s. 35; Manitoba Planning Act, s. 34(1); British Columbia Municipal Act, s. 698(1).

218. Planning Ordinance, s. 36(1).

219. "Comprehensive zoning by-laws often exempt local authorities from their provisions and permit by way of exception municipal buildings and structures to be erected on lands otherwise confined to residential uses. It would appear that such exceptions are legal." (Rogers, supra n. 92 at 144. Rogers bases his opinion on Dopp v. Kitchener, (1927) 32 O.W.N. 275.)

220. The technical difference between an "easement" and a "covenant" is sometimes confusing. For example, some organizations (such as the Ontario Heritage Foundation) working with these agreements refer to an "easement" as the interest in the "servient" land which the agreement gives rise to, whereas a "covenant" is the contract which outlines the mutual obligations of the parties. On the other hand, most texts prefer to define an easement as a proprietor's commitment not to interfere with someone else's activity on the proprietor's land (for example, a right of way), whereas a restrictive covenant is a commitment that the proprietor himself will not do something on his own land. In any event, since both easements and restrictive covenants share the same characteristics for conservation purposes, they shall be treated together in this article. 
An easement or covenant can cover a variety of subjects. The bestknown example is a right of way, where the owner of the servient tenement agrees not to interfere with the passage of someone else over his land. Similarly, an owner of land can enter into an agreement not to alter or demolish a building on his land. This is the kind of agreement which interests conservationists.

As mentioned above, most agreements do not bind future owners. If an agreement is to be classed as an easement or covenant binding on future owners, it must (at common law) meet certain standards, as described below.

\section{Common Law Standards for Easements and Restrictive Covenants}

In order for an easement or covenant to be binding upon future owners, it must spell out that the agreement is for the benefit of other land. ${ }^{221}$

Consequently, conservationists cannot obtain covenants upon property unless they own something in the area. Even then, there would have to be some indication that their own property benefited from the covenant (for example, that it retained its value as part of a heritage district, although even this "benefit" may not be concrete enough to satisfy the demands of a law in this area).

The question also arises: can an easement or covenant not only oblige an owner to tolerate something (a right of way, a building, etc.) but also to do something positive (for example, landscaping, maintenance)? At common law, the answer is "no" because a covenant must be negative in nature: "The test is whether the covenant required expenditure of money for its proper performance."222 Consequently, a covenant to repair would not be binding upon future owners. The same principle applies to easements. 223

\section{Statutory Reform}

In order to circumvent the above mentioned problems, the Alberta Historical Resources Act empowers the Minister of Culture, the Alberta Historical Resources Foundation, and the local municipality, to sign restrictive covenants which will bind future owners despite the fact that land may not be benefited or that they are "positive" in nature. 224 To qualify for such treatment, the "condition or covenant (must be one) relating to the preservation or restoration of any land or building".225

221. See Megarry, Sir Robert Edgar, A Manual of the Law of Real Property (5th ed. 1975) at 374. For example, an easement or restrictive covenant for a right of passage is for the occupants of the neighbouring land. Similarly, an easement or covenant not to demolish will not be binding on future owners unless it specifies a property (a "dominant" land) which will benefit from the agreement aside from the property being protected. On occasion, courts have even insisted that the "dominant" property must not only be specified, but must be shown to really benefit from the agreement (that is, not just nominally): for example, a restrictive covenant allegedly for the benefit of land in another community is not binding upon future purchasers because the other land is not really benefited. See Kelly v. Barret (1924) 2 Ch. 379 at 404 .

222. Megarry, supra $n$. 221 at 357. This problem had been partly dealt with under section 143 of the old Planning Act, allowing municipalities to sign "development agreements" protected by caveat. This provision was abolished and not replaced in the Planning Act, 1977. Sections 52 and 136 of the Land Titles Act did not solve this problem.

223. Megarry, supra n. 221 at 394.

224. Supra n. 32 at s8. 19.6(1) and (3).

225. Id. at s. 19.6(1). 
Such special agreements can also be signed by "an historical organization that is approved by the Minister". ${ }^{226}$ Furthermore, the agreement can be assigned to other individuals or groups.227

In one of the rare instances in which governments can intervene directly in private contracts, the Alberta Historical Resources Act has empowered the Minister of Culture to "discharge or modify (such a) condition or covenant ... whether or not he is a party to the condition or covenant" if he "considers it in the public interest to do so".228

\section{The Situation in the Northwest Territories}

No similar legislation exists in the Northwest Territories. Consequently, if one wants to sign a contract which not only binds the current owner, but also binds future owners, one must adopt a second-best solution, unless one happens to own property close by and the contract is drafted without maintenance provisions. This solution is a private agreement signed with the proprietor of the property in question; unfortunately, such an agreement is not usually binding upon future owners.

It is possible under current law to draft a contract which, without being an easement or covenant, could include many protective provisions and still have some effect upon future owners.

The contract can state that the owner will secure the signature of future buyers on the protective agreement. If future buyers refuse to sign, then the owner will be liable in damages. This technique often succeeds in assuring that future buyers will respect the contract and thus in protecting a good number of properties for the foreseeable future. Examples of such agreements can be obtained from Heritage Canada.

\section{Registration and Information}

In order to bind future owners, any easement or covenant should be registered at the local Land Titles Office.229

Such agreements have been drafted in other jurisdictions and examples are available from Heritage Canada.

\section{Fiscal Aspects}

An easement is an interest in land; proprietorship is a "bundle" of interests and to part with an interest is to part with a segment of one's proprietorship. This disposition has market value, namely, the difference in the value of the property before and after the contract.

In the United States, such a contractual agreement is considered a donation to the public of a part of one's proprietorship, and charitable tax receipts are recognized accordingly. To date, ${ }^{230}$ no one has challenged the Canadian Department of National Revenue to give the same tax treatment; the subject is currently under study.

226. Id. at 8. 19.1(1).

227. Id. at s. 19.1(4).

228. Id. at s. 19.1(5).

229. This includes the special agreements mentioned above: see id. at s. 19.1(2).

230. See the opinion of attorney Russell L. Brenneman, published in Preservation News, May, 1976 , at 3. This view was accepted by the Internal Revenue Service (U.S.) in a 1975 ruling (Rev. Rul. 75-358, 1975-34 I.R.B. Aug. 25, 1975) and U.S. Public Law 94-455, the Tax Reform Act of 1976. 


\section{A. General}

\section{PUBLIC PARTICIPATION}

"Public participation" is a term which has been discussed at length in a multiplicity of publications. This article will therefore discuss only a few aspects which are particularly germane to the protection of the built environment.

\section{B. Organization of Conservation Groups}

\section{Introduction}

There are certain advantages for heritage organizations which are officially incorporated. The principle advantages are the capacity to own property, the capacity to enter into contracts, limited liability, and usually a greater facility in obtaining charitable status.

Incorporation can be either provincial ${ }^{231}$ or federal;232 local groups usually choose to incorporate provincially. Heritage Canada can provide examples of the constitutions of similar groups.

\section{Charitable Status}

Charitable status is another valuable asset of a heritage group; it means that the group can issue tax-deductible receipts for all donations. This feature obviously constitutes an advantage in fund-raising.

The rules concerning charitable status, ${ }^{233}$ along with application forms, are available from the Charitable and Non-Profit Organizations Section of Revenue Canada. ${ }^{234}$

\section{Financial Support}

Fund raising is an inevitable necessity for conservation organizations. Funding ${ }^{235}$ for various enterprises related to conservation can be found at the federal ${ }^{236}$ and provincial ${ }^{237}$ levels, as well as in the private sector. ${ }^{238}$

231. Alberta: The Companies Branch; N.W.T.: Registrar of Companies, Department of Public Services.

232. Department of Consumer and Corporate Affairs, Hull; Quebec.

233. These rules are outlined in Revenue Canada's Info. Circular No. 77-19.

234. Revenue Canada, 400 Cumberland Street, Ottawa, K1A 0X5. Charities registered in Canada can also be recognized in the United States. This would permit Americans donating to the charity to deduct the donation from their income in Canada; it would also permit American charities to transfer funds to the Canadian charity. To obtain such advantages, a Canadian charity should complete "Package 1024" and form "SS-4", available from the United States Embassy.

235. A useful introduction to the subject is Shortcuts to Survival by Joyce Young (Shortcuts, Toronto, 1978).

236. At the time of preparing this article, new programs were being announced by C.M.H.C. Contact: Neighbourhood \& Residential Rehabilitation, Central Mortgage and Housing Corp., Ottawa. Parks Canada administers a program which subsidizes historic sites designated under the federal Historic Sites and Monuments Act. Contact: Historic Sites \& Monuments Board of Canada, Parks Canada, Ottawa. The Prairie Farm Rehabilitation Assistance Program, the Regional Development Incentive Program, and special ARDA programs can occasionally be useful. Contact: Dept. of Regional Economic Expansion, Edmonton. Government funding can also be made available in the Territories. Contact: D.R.E.E. in Yellowknife. In both Alberta and the Territories, the Dept. of Employment and Immigration has two programs, "Canada Works" and "Young Canada Works", with a relatively strong heritage orientation. The Canadian Home Insulation Program (CHIP) can provide some assistance for insulating buildings. The Katimavik program can occasionally make free, young, unskilled labour available for community projects. Contact: Katimavik, 323 Chapel Street, Ottawa, K1N 7Z2.

237. The Alberta Housing Corporation administers additional programs related to housing, such as the Senior Citizens Home Improvement Program. The Alberta Historical Resources Foundation occasionally makes grants available to worthwhile projects. Municipalities can introduce incentives for heritage properties.

238. There are some 35,000 registered charitable organizations in Canada; some can be persuaded 


\section{Powers of Citizens' Groups}

\section{General}

Heritage legislation is useless unless it is enforced. Obviously, the most expeditious way to have the law enforced is for the government to enforce it. It is conceivable, however, that government might fail to act because of oversight or conflict of interest. In such cases, public action may have a very positive impact upon the implementation of the objectives of heritage legislation.

There is, however, no formal legal mechanism to integrate public participation with the decision-making process for the designation and protection of heritage property. Federal laws are silent in this regard. On the provincial level, the Alberta Historical Resources Act foresees no public participation except at the level of submissions to the Historic Sites Board, which, in any event, is only an advisory body. The situation in the Northwest Territories is comparable. On the municipal level, the decisionmaking power in both jurisdictions is in the hands of municipal officials; there is no formalized system of continuous citizen input into the planning process as there was, for example, in the City of Winnipeg Act or in the right of compulsory referendum in Quebec municipalities. ${ }^{239}$

Furthermore, unlike the situation elsewhere, ${ }^{240}$ citizens in these two jurisdictions have no recourse which would permit them to force the government to implement its own laws. A citizen cannot, for example, compel the Alberta Minister of Culture to designate a building for protection, despite the obvious cultural value of any such structure. Conservationists, however, must also face other legal problems.

\section{Access to Information}

Information from various government levels can be important for conservationists, particularly in matters pertaining to public works. In certain jurisdictions, such as the United States, all governmental information is deemed public until declared confidential; it cannot be so classified without valid reasons. Otherwise, the courts can invoke the Freedom of Information Act ${ }^{241}$ to compel the government to disclose this information.

In Canada, the situation is different. Under the Official Secrets Act ${ }^{242}$ and related civil service oaths, all governmental information is secret until its publication is authorized. This authorization is at the exclusive discretion of the government. Citizens have no way to compel the

to donate to the conservation of the built environment. The corporate sector is another possible source of funds. See Heritage Canada's Directory of Funding Sources. Some civic beautification projects can be carried out on a purely voluntary co-operative basis. Such a project, often called a "Norwich Plan", requires good organization and promotion. Frequently, such organization comes from merchants' associations or chambers of commerce. Interesting examples of this approach, though not for heritage purposes, are found in the civic beautification projects of Kimberley and Osoyoos, British Columbia. Special arrangements may also be made to cover the cost of local improvements-for instance, $a$ beautification scheme may be paid for by the proprietors who are benefited. Further information on such projects is usually available from the local representative of the Norwich Union Insurance Company.

239. Quebec Cities and Towns Act, art. 426(1c). This right can be invoked (assuming a sufficient number of citizens demanded it) on any zoning amendment.

240. Particularly as represented by the American situation under the National Historic Preservation Act of 1966, 16 U.S.C. 8. 470(f) P.L. 89-665, particularly of 8. 106; National Environmental Policy Act, 42 U.S.C. 8. 4231 et seq., P.L. 91-190.

241. 1966 P.L. 89-554, 80 Stat. 383 as amended.

242. R.S.C. 1970 , c. $0-3$. 
government to provide information on the protection of heritage or any other subject. The same situation prevails in Alberta and the Northwest Territories. At the federal level, however, new legislation has been introduced to improve the situation.

\section{Access to Political Action}

Lobbying on behalf of private interests for entrepreneurs and speculators is not only legal in Canada, but a special provision of the Income Tax Act ${ }^{243}$ states that all such measures of political action are tax deductible. ${ }^{244}$ On the other hand, the very same measures used on behalf of the public interest are not tax deductible; and a charitable organization which undertakes such "political action" on behalf of the public interest commits an offense punishable by the loss of its charitable status. ${ }^{245}$ Although "political action" is very difficult to define,246 any charitable organization which undertakes to promote heritage conservation must do so with caution.

\section{Access to the Courts}

If an individual is harmed by an illegal act, he may sue. If the entire community is harmed by an illegal act, such as the illegal destruction of heritage, can the community sue? Alternatively, can a citizens' group do so on behalf of the community? This question underlines the principle of locus standi: this legal principle concerning the right to appear before the courts denies such access to the majority of conservationists and other citizens' groups who are working on behalf of the public interest.

If all the members of a community have been equally harmed by an illegal act (e.g., by the government), no one has access to the courts except a representative of the government (the Attorney General). In other words, it is usually necessary for the plaintiff to demonstrate that the alleged illegality will cause him more harm (physically or financially) than other members of the community. Otherwise, if only the "public interest" is at stake, he will usually be denied access to the courts. ${ }^{247}$

In some exceptional cases, it is possible for the public to use "private prosecutions"; see Environmental Management and Public Participation. ${ }^{248}$

There are also cases where citizens may take legal action in their capacity as municipal ratepayers. ${ }^{249}$ Jurisprudence on this point, however, remains somewhat unsettled.

243. Supra n. 193.

244. Id. at s. $20(1)(\mathrm{cc})$.

245. Revenue Canada Information Circular 77-14, June 20, 1977. s. 6(c). At the time of writing, litigation was pending between the Minister of National Revenue and the Manitoba Foundation for Canadian Studies over the Foundation's de-registration for alleged "political" content in the Foundation's publication Canadian Dimensions.

246. In the spring of 1978, Revenue Canada issued an information circular which so restricted the rights of charitable organizations that it had to be withdrawn.

247. See the recent case of Rosenberg and Makarchuk v. Grand River Conservation Authority (1976) 12 O.R. (2d) 496 (Ont. C.A.); leave to appeal to the Supreme Court of Ontario was refused in October, 1976.

248. P. S. Elder, ed. (Canadian Environmental Law Association, Toronto, 1976).

249. See: Re Davis and Village of Forest Hill (1965) 1 O.R. 240 at 246, and Tache Gardens et al. v. Dasken Enterprises, (1974) S.C.R. 2. 


\section{CONCLUSION}

Canada's built environment is difficult to protect. This environment, which determines the quality of life of a large part of our population, is also our habitat, with all the complications which that entails. Planning for our structural heritage is as complex as dealing with the subject of habitat itself.

There are no simple solutions. By the same token, there is no single legal mechanism which is sufficient to deal effectively with the problems facing our built environment. The proper protection of our structural heritage demands a variety of legal techniques, as well as initiative and imagination in their application.

The small size of communities in the N.W.T. has meant that redevelopment pressures have been low, and hence the demolition of historic buildings and areas is a less pressing concern. The situation in Alberta, however, is entirely different: for example, one is hard pressed in either Edmonton or Calgary to find downtown areas which have a "quaint" atmosphere and which are likely to retain it. Nevertheless, in direct response to citizens' demands, planning authorities are becoming increasingly aware of the importance of areas such as the mall in Calgary or Old Strathcona in Edmonton; and in a province which is feeling the increasing need to assert its special identity, those contacts with civic roots are likely to grow in importance. In turn, this is likely to be reflected in increased citizen demand for the entrenchment of "heritage" principles in the planning process and in the future of the collective environment. 